\title{
Zoonotic bacteria research and analysis of antimicrobial resistance levels in parrot isolates from pet shops in the city of Fortaleza, Brazil ${ }^{1}$
}

\author{
Adson R. Marques²*(D), Bruno P. Lima ${ }^{2}$ (D), Régis S.C. Teixeira² (D), \\ Átilla H. Albuquerque ${ }^{3}$, Elisângela S. Lopes ${ }^{4}$, William C. Maciel² (D), \\ Antonio Jackson F. Beleza ${ }^{2}$ (D) and Thiago R. Alencar ${ }^{2}$ (D)
}

\begin{abstract}
Marques A.R., Lima B.P., Teixeira R.S.C., Albuquerque A.H., Lopes E.S., Maciel W.C., Beleza A.J.F. \& Alencar T.R. 2021. Zoonotic bacteria research and analysis of antimicrobial resistance levels in parrot isolates from pet shops in the city of Fortaleza, Brazil. Pesquisa Veterinária Brasileira 41:e06837, 2021. Setor de Estudos Ornitológicos, Faculdade de Veterinária, Universidade Estadual do Ceará, Av. Paranjana 1700, Fortaleza, CE 60740-903, Brazil. E-mail: adsonribeiromarques@gmail.com

The Psittaciformes are among the most popular pets due to their intelligence, ability, and ease of maintenance in small environments. However, the absence of adequate environmental stimuli generated by confinement can predispose these animals to characteristic stress conditions, leaving them susceptible to the triggering of various diseases, among which those of bacterial origin stand out. The objective of this study was to carry out a survey of enterobacteria and evaluate the antimicrobial sensitivity profile of bacteria isolated from parrots from a pet shop in the city of Fortaleza, Ceará. Ninety-six samples were collected from four pet shops (which were classified as A, B, C and D), eight samples of local swabs from budgerigar (Melopsittacus undulatus), were collected from each establishment eight from cockatiels (Nymphicus hollandicus) and eight from lovebirds (Agapornis sp.). Isolation of enterobacteria is under the methodology used by Lopes et al. (2015) with modifications. The method used to study bacterial resistance was the Kirby-Bauer method, following the standards stipulated by the Clinical and Laboratory Standards Institute. Sixty-eight enterobacteria strains from ten different species, Proteus mirabilis, Citrobacter diversus, Pantoea agglomerans, Escherichia coli, Providencia stuartii, Hafnia alvei, Proteus vulgaris, Serratia liquefaciens, Enterobacter sakasakii and Citrobacter amalonaticus, were isolated. P. agglomerans was the bacterium with the highest frequency of isolates from pet shop parrots, making up $23.5 \%$ of the isolates; the second-most isolated strain was P. mirabilis with $17.7 \%$. In this study, $79 \%$ of the isolated strains were resistant to at least one class of antimicrobials tested. Tetracycline proved to be the most resistant antimicrobial (44\%), followed by polymyxin B (38\%) and nalidixic acid (25\%). Among the 68 strains, $19 \%$ did not show resistance to any of the classes of antimicrobials tested. The condition of multidrug resistance - resistance to $\geq 3$ classes of antimicrobials - was observed in $18 \%$ of the isolated strains.
\end{abstract}

INDEX TERMS: Zoonotic bacteria, antimicrobial resistance, parrot, pet shops, Brazil, birds, bacteria, antibiotic resistance, wildlife animals.

\footnotetext{
${ }^{1}$ Received on April 12, 2021.

Accepted for publication on May 19, 2021.

${ }^{2}$ Laboratório de Estudos Ornitológicos, Faculdade de Veterinária, Universidade Estadual do Ceará (UECE), Av. Paranjana 1700, Fortaleza, CE 60740-903, Brazil.*Corresponding author: adsonribeiromarques@gmail.com

${ }^{3}$ Setor de Microbiologia, Laboratório BIOLAB S/C Ltda., Fortaleza, CE, Brazil.

${ }^{4}$ Coordenação, Hospital Veterinário de Caucaia, Caucaia, CE, Brazil.
}

RESUMO.- [Pesquisa de bactérias zoonóticas e análise dos níveis de resistência antimicrobiana em isolados de psitacídeos de pet shops da cidade de Fortaleza, Brasil.] Os psittaciformes estão entre os animais de estimação mais populares devido sua inteligência, habilidade, além da facilidade de manutenção da espécie em pequenos ambientes. Contudo, a ausência de estímulos ambientais adequados gerados pelo confinamento, podem predispor esses 
animais a quadros característicos de estresse, deixando-os susceptíveis ao desencadeamento de várias doenças dentre elas se destacam as de origem bacteriana. 0 objetivo desse trabalho foi realizar uma pesquisa de enterobactérias e avaliar o perfil de sensibilidade antimicrobiana de bactérias isoladas de psitacídeos de pet shop da cidade de Fortaleza, Ceará. Foram coletadas 96 amostras de quatro pet shops (os quais foram classificados em A, B, C e D), sendo coletados de cada estabelecimento oito amostras de suabes clocais oriundos de periquitos australianos (Melopsittacus undulatus), oito de calopsitas (Nymphicus hollandicus) e oito de agapornis (Agapornis sp.). $\mathrm{O}$ isolamento de enterobactérias está de acordo com a metodologia utilizada por Lopes et al. (2015) com modificações. 0 método utilizado para o estudo de resistência bacteriana foi o de Kirby-Bauer, seguindo os padrões estipulados pela Clinical and Laboratory Standards Institute. Foi isolado um total de 68 cepas de enterobactérias, de dez espécies diferentes, Proteus mirabilis, Citrobacter diversus, Pantoea agglomerans, Escherichia coli, Providencia stuartii, Hafnia alvei, Proteus vulgaris, Serratia liquefaciens, Enterobacter sakasakii e Citrobacter amalonaticus. Pantoea agglomerans foi a bactéria com maior percentagem de frequência dos isolados de psitacídeos de pet shop, perfazendo um total de 23,5\% dos isolados, a segunda cepa mais isolada foi Proteus mirabilis com $17,7 \%$. Neste estudo $79 \%$ das cepas isoladas foram resistentes a pelo menos uma classe de antimicrobianos testados, tetraciclina demonstrou ser o antimicrobiano com maior resistência (44\%), seguido da polimixina B (38\%) e do ácido nalidíxico (25\%). Dentre as 68 cepas isoladas, 19\% não apresentaram resistência a qualquer uma das classes de antimicrobianos testadas. A condição de multirresistência, ou seja, resistência a $\geq 3$ classes de antimicrobianos foi observado em $18 \%$ das cepas isoladas.

TERMOS DE INDEXAÇÃO: Bactérias zoonóticas, resistência antimicrobiana, psitacídeos, pet shops, Brasil, aves, bactérias, resistência a antibióticos, animais selvagens.

\section{INTRODUCTION}

Birds of the order Psittaciformes are widespread throughout the world and comprise more than 350 species distributed in four families: Psittacidae (African parrots), Psittaculidae (parrots, macaws and parakeets), Strigopidae (New Zealand parrots) and Cacatuidae (cockatoos) (Gill \& Donsker 2019). Parrots are currently the most popular pets due to their intelligence, ability, and ease of maintenance in small environments. Among the most sought after are the budgerigars (Melopsittacus undulatus), cockatiels (Nymphicus hollandicus) and parrots (Amazona aestiva) (Dlugosz et al. 2015).

Several diseases are transmitted from domestic birds to humans through direct or indirect contact with sick birds or asymptomatic carriers. Among these diseases, those of bacterial origin stand out, considered the most common zoonotic agents (Akhter et al. 2010). Among the bacteria identified as important avian pathogens related to management failures in captive birds, those belonging to the Enterobacteriaceae family stand out (Janda \& Abbot 2008). The most problematic enterobacteria for Psittaciformes are Escherichia coli, Yersinia spp. and Salmonella spp., hence the importance of parrots to public health due to their potential to harbor zoonotic pathogens (Simpson 1996).
Concerns about antimicrobial resistance are currently on the rise, in addition to the zoonotic potential of these enterobacteria (Cunha et al. 2013, Hidasi et al. 2013, Mekes et al. 2020, Falagas et al. 2021, Yuan et al. 2021). The widespread use of antimicrobial drugs, both in the treatment of diseases and animal production, resulted in selective pressure and the consequent emergence of multiresistant bacteria (Allen et al. 2010). Therefore, this study aimed to investigate enterobacteria from parrots from pet shops in Fortaleza, Ceará and evaluate the antimicrobial sensitivity profile of the isolated bacterial strains.

\section{MATERIALS AND METHODS}

Sampling. Ninety-six samples were collected from four pet shops (which were classified as A, B, C and D) located in the city of Fortaleza/CE, with eight samples of local swabs from budgerigars (Melopsittacus undulatus), eight from cockatiels (Nymphicus hollandicus) and eight from lovebirds (Agapornis sp.). The choice of each establishment was made by convenience (non-probabilistic sampling), and the selection of each genus of birds was random.

Microbiological processing of enterobacteria. Isolation of enterobacteria is under the methodology used by Lopes et al. (2015) with modifications as follows: the samples were placed in $10 \mathrm{~mL}$ of $1 \%$ Peptone Water $\left(\operatorname{Kasvi}^{\circledR}\right)$, and after arrival at the "Laboratório de Estudos Ornitológicos" (LABEO), they were incubated in a microbiological incubator for $24 \mathrm{~h} / 37^{\circ} \mathrm{C}$. Subsequently, $1 \mathrm{~mL}$ aliquots of each sample were transferred to selective Selenite Cystine $\left(\mathrm{Kasvi}^{\circledR}\right)$ and Brain Heart Infusion $\left(\mathrm{Kasvi}^{\circledR}\right)$ enrichment broths, respectively. These solutions were incubated for $24 \mathrm{~h} / 37^{\circ} \mathrm{C}$. After selective enrichment, each broth was seeded in two culture media, on Hektoen agar (Himedia ${ }^{\circledR}$ ) and MacConkey agar $\left(\mathrm{Kasvi}^{\circledR}\right)$, then the plates were incubated for $24 \mathrm{~h} / 37^{\circ} \mathrm{C}$. Different colonies were collected on each plate and inoculated into tubes containing Triple Sugar Iron Agar (Kasvi $\left.{ }^{\circledR}\right)$. A biochemical battery consisting of the following means was used to confirm the enterobacteria: SIM Medium (Himedia ${ }^{\circledR}$ ), lysine-decarboxylase $\left(\operatorname{Kasvi}^{\circledR}{ }^{\text {), }}\right.$, ornithine-decarboxylase (Himedia ${ }^{\circledR}$ ), MR-VP broth (Himedia ${ }^{\circledR}$ ), urea (Dynamic Formula ${ }^{\circledR}$ ), Simmons Citrate agar (Himedia ${ }^{\circledR}$ ), arginine decarboxylase (Exodus Cientifica ${ }^{\circledR}$ ), malonate broth (Himedia ${ }^{\circledR}$ ), production of $\mathrm{H} 2 \mathrm{~S}$, glucose fermentation (with gas production), lactose $\left(\right.$ Merck $^{\circledR}$ ), sucrose (Dinâmica ${ }^{\circledR}$ ), mannitol (Dinâmica ${ }^{\circledR}$ ), arabinose (Dinâmica ${ }^{\circledR}$ ), raffinose (Dinâmica ${ }^{\circledR}$ ), sucrose (Dinâmica ${ }^{\circledR}$ ), dulcitol (Dinâmica ${ }^{\circledR}$ ), adonitol (Dinâmica ${ }^{\circledR}$ ), inositol (Sigma ${ }^{\circledR}$ ) and sorbitol $\left(\right.$ Sigma $^{\circledR}$ ) (Holt et al. 1994, Koneman et al. 2008). Suspicious samples for Salmonella spp. were submitted to the agglutination test using the polyvalent serum " $O$ " (Probac ${ }^{\circledR}$ ), and were later sent to the FIOCRUZ reference laboratory for serotyping.

Sensitivity profile of enterobacteria (antimicrobial susceptibility test). The method used to study bacterial resistance was the KirbyBauer method, following the standards stipulated by the Clinical and Laboratory Standards Institute (CLSI 2017). The following pharmacological classes were used to analyze the resistance profile of the isolated strains: 1) Aminoglycosides (streptomycin, $10 \mu \mathrm{g}$ and gentamicin, $10 \mu \mathrm{g}$ ); 2) Sulfonamides (sulfonamide, $300 \mu \mathrm{g}$ and sulfazotrim (sulfamethoxazole + trimethoprim), 25 $\mu \mathrm{g}$ ); 3) Beta-lactams

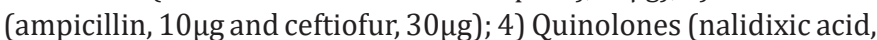
$30 \mu \mathrm{g}$ and ciprofloxacin, $5 \mu \mathrm{g}$ ); 5) Polymyxins (polymyxin B, 300 $\mathrm{gg}$ ); 6) Tetracyclines (tetracycline, $30 \mu \mathrm{g}$ ). Multidrug resistance (MDR) was considered when the strains were resistant to at least three classes of antimicrobials (Magiorakos et al. 2012). For this purpose, the samples were previously retrieved in tubes containing $10 \mathrm{~mL}$ of $\mathrm{BHI}$, being placed in a bacteriological incubator for 24 hours at $37^{\circ} \mathrm{C}$. 
Subsequently, aliquots of the broth were seeded onto MacConkey agar plates and again incubated in an oven. Afterward, two to three units of bacterial colonies present on MacConkey agar were selected and seeded in $5 \mathrm{~mL}$ tubes of saline solution. Then, a swab was moistened in the turbid saline solution and streaked on the surface of a plate containing Mueller-Hinton agar $\left(\mathrm{Kasvi}^{\circledR}\right)$, in which the antimicrobial discs were introduced. The plates were incubated at $37^{\circ} \mathrm{C}$ for $24 \mathrm{~h}$, and their reading was performed and interpreted according to the presence or absence of halos surrounding the drug discs, classified as resistant, intermediate or sensitive.

\section{Bacterial isolation}

\section{RESULTS}

Of the 96 samples collected, 68 enterobacteria strains were isolated from 10 different species, Proteus mirabilis, Citrobacter diversus, Pantoea agglomerans, Escherichia coli, Providencia stuartii, Hafnia alvei, Proteus vulgaris, Serratia liquefaciens, Enterobacter sakasakii and Citrobacter amalonaticus (Table 1). In pet shop $\mathrm{A}$, two strains were isolated, one of $C$. diversus and one of E. coli. In pet shop B, 45 strains were isolated with the highest prevalence of $P$. mirabilis. In pet shop C, 13 enterobacteria were isolated, with P. agglomerans being the most prevalent. In pet shop D, eight strains were isolated with a higher prevalence of $E$. coli. In the samples collected from cockatiels (Nymphicus hollandicus), 72.87\% (23/32) were positive for enterobacteria, with greater isolation of $P$. agglomerans $(21.87 \%)$. In the budgerigars (M. undulatus),
$65.62 \%(21 / 32)$ were positive for enterobacteria, being the most isolated P. agglomerans (18.75\%); in lovebirds (Agapornis sp.), 75\% (24/32) were positive for enterobacteria with a higher frequency of isolate P. mirabilis (18.75\%) (Table 2). $P$. agglomerans was the bacterium with the highest frequency of isolates from pet shop parrots, making up 23.5\% of the isolates; the second-most isolated strain was P. mirabilis with $17.7 \%$. For the bacteria Citrobacter amalonaticus and $P$. vulgaris, only one strain of each bacterium was isolated.

\section{Antimicrobial resistance}

Tetracycline proved to be the antimicrobial by which the strains showed greater resistance with a survival rate of $44 \%$, followed by polymyxin B (38\%) and nalidixic acid (25\%). Among the bacterial species isolated, $50 \%$ of the strains of P. agglomerans were resistant to tetracycline. Resistance to polymyxin B (37\%) and streptomycin (31\%) was also observed. P. mirabilis showed high resistance to tetracycline and polymyxin B, both with $83 \%$ resistance. S. liquefaciens showed resistance to sulfonamide and nalidixic acid, both with 55\% resistance. All strains were sensitive to ceftiofur (Table 3). Among the 68 strains isolated in this study, 19\% did not show resistance to any of the classes of antimicrobials tested. The condition of multidrug resistance - resistance to $\geq 3$ classes of antimicrobials - was observed in $18 \%$ of the isolated strains (Table 4). Intermediate strains were not observed in the present study.

Table 1. Frequency of bacterial isolates from 96 individual cloacal samples collected from pet shop parrots (A, B, C and D) in the city of Fortaleza

\begin{tabular}{llcccc}
\hline \multicolumn{1}{c}{ Isolated bacteria } & A & B & C & D & Total/Percentage \\
\hline Pantoea agglomerans & - & 9 & 5 & 2 & $16(23.5 \%)$ \\
Proteus mirabilis & - & 10 & - & 2 & $12(17.7 \%)$ \\
Serratia liquefaciens & - & 7 & 2 & - & $9(13.2 \%)$ \\
Citrobacter diversus & 1 & 6 & 1 & 1 & $9(13.2 \%)$ \\
Escherichia coli & 1 & 2 & 3 & 3 & $9(13.2 \%)$ \\
Hafnia alvei & - & 5 & 1 & - & $6(8.8 \%)$ \\
Providencia stuartii & - & 3 & - & - & $3(4.4 \%)$ \\
Enterobacter sakasakii & - & 1 & 1 & - & $2(3 \%)$ \\
Citrobacter amalonaticus & - & 1 & - & - & $1(1.5 \%)$ \\
Proteus vulgaris & - & 1 & - & - & $1(1.5 \%)$ \\
TOTAL & 2 & 45 & 13 & 8 & $68(100 \%)$
\end{tabular}

Table 2. Frequency of bacterial isolates from budgerigars (Melopsittacus undulatus), lovebirds (Agapornis sp.) and cockatiels (Nymphicus hollandicus)

\begin{tabular}{lccc}
\hline \multicolumn{1}{c}{ Isolated bacteria } & M. undulatus $(\mathrm{n}=32)$ & $\begin{array}{c}\text { Agapornis sp. } \\
(\mathrm{n}=32)\end{array}$ & $\begin{array}{c}\text { N. hollandicus } \\
(\mathrm{n}=32)\end{array}$ \\
\hline Pantoea agglomerans & $6(18.75 \%)$ & $3(9.37 \%)$ & $7(21.87 \%)$ \\
Proteus mirabilis & $3(9.37 \%)$ & $6(18.75 \%)$ & $3(9.37 \%)$ \\
Serratia liquefaciens & $1(3.12 \%)$ & $4(12.5 \%)$ & $4(12.5 \%)$ \\
Citrobacter diversus & $3(9.37 \%)$ & $5(15.62 \%)$ & $1(3.12 \%)$ \\
Escherichia coli & $3(9.37 \%)$ & $2(6.25 \%)$ & $4(12.5 \%)$ \\
Hafnia alvei & $1(3.12 \%)$ & $3(9.37 \%)$ & $2(6.25 \%)$ \\
Providencia stuartii & $2(6.25 \%)$ & $1(3.12 \%)$ & 0 \\
Enterobacter sakasakii & $1(3.12 \%)$ & 0 & $1(3.12 \%)$ \\
Citrobacter amalonaticus & $1(3.12 \%)$ & 0 & 0 \\
Proteus vulgaris & 0 & 0 & $1(3.12 \%)$ \\
TOTAL & $21(65.62 \%)$ & $24(75 \%)$ & $23(72.87 \%)$
\end{tabular}


Table 3. Frequency of antimicrobial resistant enterobacteria tested from samples isolated from pet shop parrots in Fortaleza

\begin{tabular}{|c|c|c|c|c|c|c|c|c|c|c|}
\hline Isolated bacteria & AMP & GEN & EST & SUL & CIP & SUT & TET & CFT & POL & NAL \\
\hline Pantoea agglomerans(16) & 2 & - & 5 & 4 & - & 4 & 8 & - & 6 & 1 \\
\hline Proteus mirabilis(12) & - & - & 1 & - & - & - & 10 & - & 10 & 1 \\
\hline Serratia liquefaciens(9) & 1 & 2 & 2 & 5 & 1 & 3 & 1 & - & - & 5 \\
\hline Citrobacter diversus(9) & 3 & - & - & - & - & - & 2 & - & 2 & - \\
\hline Escherichia coli (9) & 2 & 1 & 1 & 2 & 1 & 2 & 2 & - & 2 & 1 \\
\hline Hafniaalvei (6) & - & - & 1 & 3 & 1 & 2 & 2 & - & - & 5 \\
\hline Providencia stuartii $(3)^{\dagger}$ & - & 3 & - & - & - & - & 3 & - & 3 & 1 \\
\hline Enterobacter sakasakii (2) & - & - & - & 1 & - & 1 & - & - & 1 & 2 \\
\hline Citrobacter amalonaticus (1) & - & 1 & 1 & 1 & - & - & 1 & - & - & 1 \\
\hline Proteus vulgaris (1) & - & - & - & - & - & - & 1 & - & 1 & - \\
\hline TOTAL (68) & 8 & 7 & 12 & 16 & 3 & 12 & 30 & - & 25 & 17 \\
\hline
\end{tabular}

AMP = ampicillin, GEN = gentamicin, EST = streptomycin, SUL = sulfonamide, CIP = ciprofloxacin, SUT = sulfamethoxazole+trimethoprim, $\mathrm{TET}=$ tetracycline, $\mathrm{CFT}=$ ceftiofur, $\mathrm{POL}=$ polymyxin $\mathrm{B}, \mathrm{NAL}=$ nalidixic acid $;{ }^{\dagger}$ Providencia stuartii intrinsic resistance to gentamicin.

Table 4. Multidrug-resistant enterobacteria (MDR) isolated from pet shop parrots

\begin{tabular}{cc}
\hline Number of antibiotic classes & Number of resistant strains (\%) \\
\hline 0 & $13(19 \%)$ \\
1 & $18(26 \%)$ \\
2 & $24(35 \%)$ \\
3 & $6(9 \%)$ \\
4 & $5(7 \%)$ \\
5 & $1(1 \%)$ \\
6 & $1(1 \%)$ \\
Total & $68(100 \%)$
\end{tabular}

\section{DISCUSSION}

The absence of Salmonella spp. has been reported in several recent Brazilian studies on birds raised in captivity, with little or no detection of this bacterium in apparently healthy birds (Horn et al. 2015, Lopes et al. 2015). Gopee et al. (2000) mention that free-living birds are identified as potential carriers of pathogens to the interior of animal herds but that the frequency of Salmonella spp. in captive birds is relatively low compared to mammals and reptiles.

According to the study by Dlugosz et al. (2015), Salmonella spp. was also not isolated in 86 fecal samples of cockatiels kept in a domestic environment in the metropolitan region of Curitiba. In Ceará, a research was carried out with budgerigars and cockatiels from the domestic environment, not being isolated Salmonella spp. (Bezerra et al. 2013, Lima 2016). Retrospective studies reinforce the difficulty in isolating the agent in these species. As for lovebirds, there is no specific research in Brazil for this species.

Of the 96 samples collected in that study, 68 were positive (70\%) for bacterial growth, which corroborates the research by Lopes et al. (2015), who found the presence of enterobacteria in about $71 \%$ of the 167 parrots investigated. These findings indicate that the rate of isolation of enterobacteria in cloacal samples of parrots occurs at a high level. As the birds were healthy, it can be assumed that these microorganisms are occurring in equilibrium with the intestinal microbiota without causing any apparent clinical disease.

The most isolated microorganism in this study was Pantoea agglomerans, a bacterium commonly found in the environment, which is rarely responsible for infections in humans, although it is often a causative factor of a series of occupational diseases (Büyükcam et al. 2018). The most common P. agglomerans infections in humans involved wound infections $(35.7 \%)$, pneumonia $(21.4 \%)$ and urinary tract infections (21.4\%) (Büyükcam et al. 2018). P. agglomerans has been identified as a possible cause of disease in vertebrate animals, but compared to humans, there are only a few reports of infections in this group (Dutkiewicz et al. 2016). Commonly found in nature, especially in plants, water, soil, and animals (Delétoile et al. 2009), this bacterium has also been isolated in clinically healthy poultry, being the most isolated in that study, with $25 \%$ positivity (Beleza et al. 2019).

The second most isolated microorganism belongs to the Proteus mirabilis species. It is considered an opportunistic microorganism that can cause disorders in the upper respiratory system and pododermatitis, associated with infections in wild birds (Olinda et al. 2012). P. mirabilis is the second most common cause of urinary tract infections in humans after Escherichia coli (Pishbin \& Mehrabian 2020).

According to Fudge (2001), Serratia spp. cause opportunistic infections in mammals, including humans. Although this microorganism is not part of the physiological microbiota of parrots and predators, the association of Serratia spp. with the disease in these species, what can occur is an impairment of the general status of the bird.

In the present study, nine strains of $E$. coli were isolated, representing $13 \%$ positivity. The percentage of isolation of E.coli is below the average of researches carried out with captive parrots in Brazil. Hidasi et al. (2013) obtained 33.9\% isolation, Lopes et al. (2015) 46.5\% and Lima (2020) 73.1\%. The low isolation index may be associated with several factors, such as using antimicrobials as growth promoters, among others.

E. coli is part of the microbiota of apparently healthy birds. However, some strains with virulence genes can cause severe disease in both birds and humans, and under immunodeficiency conditions, it can be a potential causative agent of secondary infections. The maintenance of parrots in the domestic environment contributes to the conservation of the species, but the captive environment can favor intestinal colonization by enterobacteria (Knöbl et al. 2017).

There was the lowest percentage of isolated strains with $3 \%$ in pet shop A, and pet shop B had the highest isolation rate with $66 \%$. Several factors can be related to a high rate of isolation of enterobacteria, poor management of the 
environment or animals, incorrect hygiene of feeders and drinkers, prophylactic antibiotic therapy, contact with freerange birds, breeding with different species and excess of individuals per cage, which may predispose to stress and subsequent low immunity.

In the studies carried out by Machado et al. (2018) and Teixeira (2019), there was high sensitivity to ceftiofur in the antimicrobial sensitivity test, results similar to those found in this research. However, other studies demonstrate a high rate of resistance to ceftiofur, Matias et al. (2016) had 71.67\% resistance to the antimicrobial mentioned above.

The increase in antimicrobial resistance rates in the Enterobacteriaceae family significantly reduces the number of effective medications that can be used to treat infections caused by these pathogens (Falagas et al. 2010). In this study, $79 \%$ of the isolated strains were resistant to at least one class of antimicrobials tested.

In the study by Lima (2016), the highest rates of antimicrobial resistance of enterobacteria isolated from captive parrots were sulfonamide (54.4\%), followed by amoxicillin (20.2\%) and tetracycline $(17.7 \%)$. In research on parrots, studies that assess the antimicrobial sensitivity of members of the Enterobacteriaceae family are not uniform (Lopes et al. 2015, Matias et al. 2016, Teixeira 2019, Lima 2020).

The high resistance rates for the isolated bacteria suggest greater caution in the use of these drugs. Lopes et al. (2015) evaluated enterobacteria isolates from trafficking parrots and detected an antimicrobial resistance rate for tetracycline of $48.7 \%$. In this study, tetracycline proved to be the antimicrobial to which the strains were more resistant (44\%) when compared to other antimicrobials, followed by polymyxin B (38\%) and nalidixic acid (25\%). Hidasi et al. (2013), when analyzing parrots from Cetas/G0, detected $64.5 \%$ resistance rates for tetracycline, which denotes the importance of resistance to this antimicrobial in terms of therapies to combat bacteria belonging to the Enterobacteriaceae family.

Studies of resistance to tetracyclines naturally occurring in autoch thonous environmental bacteria, representative of populations existing before the extensive use of tetracyclines, support the view that the emergence of resistance is an event that followed the introduction of these agents in human, veterinary and agroindustry use (Roberts 2005). Tetracycline is one of the main antimicrobials used in the treatment of bacterial diseases in birds. Today there are several specific commercial formulations for birds, powder solutions, liquids, and formulations for parenteral administration. The lack of control in the distribution and sale of this drug in veterinary stores and its indiscriminate use by the population may aggravate the emergence of resistant enteropathogens, as observed in the present study.

Among the bacterial species studied, $50 \%$ of the strains of P. agglomerans were resistant to tetracycline. In other studies that isolated P. agglomerans, they obtained different resistance patterns, with the highest rates being for ampicillin (52.2\%) and sulfonamides (34.8\%) (Lopes et al. 2015).

The multidrug resistance rate in this study was $18 \%$. Lopes et al. (2015) had $57.8 \%$ of multidrug resistance in isolated samples of parrots from trafficking, while Lima (2020) observed a total of nine multidrug-resistant strains of the 117 strains tested. Hidasi et al. (2013) had 40 samples (23.25\%) in multi-resistance conditions. The findings in this research and data in the literature does not suggest a pattern for the multi-resistance condition, a factor that may be related to the use of different antimicrobials in that group of birds in that particular region.

Although enterobacteria with a high rate of antimicrobial multi-resistance have not been evidenced, the presence of resistant strains, including more than one antimicrobial, becomes a problem. There is the possibility of developing multiresistant strains with the transfer of resistance genes to other bacterial species. This scenario is likely to trigger an epidemiological picture of dissemination to keepers and other animals from the same domestic environment.

\section{CONCLUSIONS}

It was found that budgerigars (Melopsittacus undulatus), cockatiels (Nymphicus hollandicus) and lovebirds (Agapornis sp.) from pet shops harbor bacteria potentially pathogenic to other animals, including humans. Pantoea agglomerans were the most isolated bacterium in clinically healthy parrots, an opportunistic pathogen that can cause diseases in birds and humans under certain conditions.

Tetracycline proved to be the antimicrobial by which the strains showed greater resistance when compared to other antimicrobials. The indiscriminate use of tetracyclines in veterinary trades and clinics has triggered accelerated and aggressive resistance to these antimicrobials. Therefore, monitoring the use and consumption of antimicrobials in pet birds must be reinforced and adhered to by veterinarians and pharmaceutical industries.

The intelligent use of antimicrobials in clinical routine and animal production is still the best way to prevent the increase and spread of bacterial resistance. The collection of this information, innovative research, and exchange of information between universities, research centers, and health professionals are essential to suppress the effects of bacterial multi-resistance and its consequences on the population health.

Therefore, it is essential to routinely microbiological monitoring of birds in these breeding sites so that, through isolation, bacterial identification and antimicrobial susceptibility testing, an adequate antibiotic therapy program can be instituted and appropriate adjustments in the management of these birds.

Conflict of interest statement.- The authors declare no conflict of interest.

\section{REFERENCES}

Akhter J., Hossain M.T., Islam M.T., Siddique M.P \& Islam M.A. 2010. Isolation and identification of microflora from apparently healthy caged parrots of Dhaka Zoo of Bangladesh. Bangl. J. Vet. Med. 8(1):5-10. <https://dx.doi. org/10.3329/bjvm.v8i1.8349>

Allen H.K., Donato J., Wang H.H., Cloud-hansen K.A., Davies J. \& Handelsman J. 2010. Call of the wild: antibiotic resistance genes in natural environments. Nat. Rev. Microbiol. 8(4):251-259. <https://dx.doi.org/10.1038/nrmicro2312> $<$ PMid:20190823>

Beleza A.J.F., Maciel W.C., Carreira A.S., Bezerra W.G.A., Carmo C.C., Havt A., Gaio F.C. \& Teixeira R.S.C. 2019. Detection of Enterobacteriaceae, antimicrobial susceptibility, and virulence genes of Escherichia coli in canaries (Serinus canaria) in northeastern Brazil. Pesq. Vet. Bras. 39(3):201-208. <https:// dx.doi.org/10.1590/1678-5150-PVB-5829> 
Bezerra W.G.A., Cardoso W.M., Teixeira R.S.C., Vasconcelos R.H., Machado D.N., Lopes E.S., Albuquerque Á.H. \& Rocha-e-Silva R.C. 2013. Survey of Salmonella sp. in budgerigars (Melopsittacus undulatus) in Fortaleza, Brazil. Acta Scient. Vet. 41:1-7.

Büyükcam A., Tuncer Ö., Gür D., Sancak B., Ceyhan M., Cengiz A.B. \& Kara A. 2018. Clinical and microbiological characteristics of Pantoea agglomerans infection in children. J. Infect. Publ. Health 11(3):304-309. <https://dx.doi. org/10.1016/j.jiph.2017.07.020><PMid:28780309>

CLSI 2017. Performance standards for antimicrobial susceptibility testing. m100-s27th. Clinical and Laboratory Standards Institute, Wayne, PA. 282p.

Cunha M.P.V., Menão M.C., Ferreira A.J.P \& Knöbl T.A. 2013. A similaridade genética de Escherichia coli patogênica para as aves (APEC) com estirpes humanas e a resistência antimicrobiana justifi cam a preocupação sanitária em relação aos produtos de origem aviária? Revta Educ. Cont. Med. Vet. Zootec. 11(2):22-33. <https://dx.doi.org/10.36440/recmvz.v11i2.16220>

Delétoile A., Decré D., Courant S., Passet V., Audo J., Grimont P., Arlet G \& Brisse S. 2009. Phylogeny and identification of Pantoea species and typing of Pantoea agglomerans strains by multilocus gene sequencing. J. Clin. Microbiol. 47(2):300-310.<https://dx.doi.org/10.1128/JCM.01916-08>

Dlugosz A.P., Santin E., Hayashi R.M., Lourenço M.C \& Silva A.B. 2015. Prevalência de Salmonella Sp. em calopsitas (Nymphicus Hollandicus) mantidas em cativeiro comercial. Arch. Vet. Sci. 20(2):155-160.<https:// dx.doi.org/10.5380/avs.v20i2.38888>

Dutkiewicz J., Mackiewicz B., Lemieszek M.K., Golec M \& Milanowski J. 2016. Pantoea agglomerans: a mysterious bacterium of evil and good. Part III. Deleterious effects: infections of humans, animals and plants. Ann. Agric. Environ. Med. 23(2):197-205. <https://dx.doi.org/10.5604/12321966.1203878> $<$ PMid:27294620>

Falagas M.E., Kastoris A.C., Kapaskelis A.M. \& Karageorgopoulos D.E. 2010. Fosfomycin for the treatment of multidrug-resistant, including extendedspectrum beta-lactamase producing, Enterobacteriaceae infections: a systematic review. Lancet Infect. Dis. 10(1):43-50. <https://dx.doi. org/10.1016/S1473-3099(09)70325-1><PMid:20129148>

Falagas M.E., Kyriakidou M., Voulgaris G.L., Vokos F., Politi S. \& Kechagia K.S 2021. Clinical use of intravenous polymyxin B for the treatment of patients with multidrug resistant Gram-negative infections: an evaluation of the current evidence. J. Glob. Antimicrob. Resist. 24:342-359. <https://dx.doi. org/10.1016/j.jgar.2020.12.026><PMid:33486122>

Fudge A.M. 2001. Diagnosis and treatment of avian bacterial diseases. Semin. Avian Exotic Pet Med.10(1):3-11.<https://dx.doi.org/10.1053/saep.2001.19542>

Gill F. \& Donsker D. 2019. IOC World Bird List (v 9.2).

Gopee N.V., Adesiyun A.A. \& Caesar K. 2000. Retrospective and longitudinal study of salmonellosis in captive wildlife in Trinidad. J. Zoo Wildl. Med. 36(2):284-293. <https://dx.doi.org/10.7589/0090-3558-36.2.284> $<$ PMid:10813610>

Hidasi H.W., Hidasi Neto J., Moraes D.M.C., Linhares G.F.C., Jayme V.S \& Andrade M.A. 2013. Enterobacterial detection and Escherichia coli antimicrobial resistance in parrots seized from the illegal wildlife trade. J. Zoo Wildl. Med. 44(1):1-7. <https://dx.doi.org/10.1638/1042-7260-44.1.1> $<$ PMid:23505696>

Holt J.G., Krieg N.R., Sneath P.H.A., Staley J.T \& Williams S.T. 1994. Bergey's Manual of Determinative Bacteriology. 9th ed. Willians and Wilkins, Baltimore. 787p.

Horn R.V., Cardoso W.M., Lopes E.S., Teixeira R.S.C., Albuquerque A.H., Rocha-e-Silva R.C., Machado D.N \& Bezerra W.G.A. 2015. Identification and antimicrobial resistance of members from the Enterobacteriaceae family isolated from canaries (Serinus canaria). Pesq. Vet. Bras. 35(6):552-556. <https://dx.doi.org/10.1590/S0100-736X2015000600011>

Janda J.M. \& Abbo S.L. 2008. The Family Enterobacteriaceae - Practical Handbook of Microbiology. 2nd ed. ACRC title, p.217-219.
Knöbl P.V., Viveiros J.F., Franco L.S., Davies Y.M., Cunha M.P.V., Menão M.C., Sato M.I.Z., Gomes V.T.M., Moreno A.M., Hidasi H.W., Souza C.A.I \& Knöbl T. 2017. Identificação de Klebsiella spp. em fezes de psitacídeos cativos. Atas Saúde Amb. 5:189-194.

Koneman E.W., Allen S.D., Janda W.M., Procop G., Schreckenberg P \& Woods G. 2008. Diagnóstico Microbiológico: texto e atlas colorido. 6a ed. Guanabara Koogan, Rio de Janeiro. 1760p.

Lima B.P. 2020. Isolamento, tipificação e perfil de sensibilidade de enterobactérias oriundas de psitacídeos de zoológicos e criadouros comerciais do estado do Ceará, Brasil. Master's Thesis, Universidade Estadual do Ceará, Fortaleza, p.46-51.

Lima S.V.G. 2016. Pesquisa microbiológica em calopsitas (Nymphicus hollandicus) oriundas de pet shops e residências de Fortaleza, Ceará. Master's Thesis, Universidade Estadual do Ceará, Fortaleza, p.62-65.

Lopes E.S., Maciel W.C., Albuquerque Á.H., Machado D.N., Bezerra W.G.A., Vasconcelos R.H., Lima B.P., Gonçalves G.A.M. \& Teixeira R.S.C. 2015. Prevalence and antimicrobial resistance profile of enterobacteria isolated from Psittaciformes of illegal wildlife trade. Acta Scient. Vet. 43:1-9.

Machado D.N., Lopes E.S., Albuquerque A.H., Horn R.V., Bezerra W.G.A., Siqueira R.A.S., Lopes I.T., Nunes F.P., Teixeira R.S.C. \& Cardoso W.M. 2018. Isolation and antimicrobial resistance profiles of Enterobacteria from nestling grey-breasted parakeets (Pyrrhura griseipectus). Revta Bras. Ciênc. Avic. 20(1):103-110. <https://dx.doi.org/10.1590/1806-9061-2017-0551>

Magiorakos A.P., Srinivasan A., Carey R.B., Carmeli Y., Falagas M.E., Giske C.G., Harbarth S., Hindler J.F., Kahlmeter G., Olsson-Liljenquist B., Paterson D.L., Rice L.B., Stelling J., Struelens M.J., Vatopoulos A., Weber J.T. \& Monnet D.L. 2012. Multidrug-resistant, extensively drug-resistant and pandrug-resistant bacteria: an international expert proposal for interim standard definitions for acquired resistance. Clin. Microbiol. Infect. 18(3):268-281. <https://dx.doi.org/10.1111/j.1469-0691.2011.03570.x> $<$ PMid:21793988>

Matias C.A.R., Pereira I.A., Reis E.M.F., Rodrigues D.P. \& Siciliano S. 2016. Frequency of zoonotic bacteria among illegally traded wild birds in Rio de Janeiro. Braz. J. Microbiol. 47(4):882-888. <https://dx.doi.org/10.1016/j. bjm.2016.07.012><PMid:27528081>

Mekes A.E., Zahlane K., Said L.A., Ouafi A.T. \& Barakate M. 2020. The clinical and epidemiological risk factors of infections due to multidrug resistant bacteria in an adult intensive care unit of University Hospital Center in Marrakesh-Morocco. J. Infect. Publ. Health 13(4):637-643.<https://dx.doi. org/10.1016/j.jiph.2019.08.012><PMid:31537511>

Olinda R.G., Souza M.C.A., Figueiredo J.N., Silva J.M.C., Alves N.D., Bezerra F.S.B. \& Feijó F.M.C. 2012. Diagnosis of Proteus spp. in wild birds raised under captivity in Rio Grande do Norte, Brazil. Arq. Inst. Biol., São Paulo, 79(2):301-303.

Pishbin Z. \& Mehrabian S. 2020. Molecular analysis of Proteus mirabilis isolated from urine samples using ERIC-PCR. Gene Reports 19(4):100637. <https://dx.doi.org/1016/j.genrep.2020.100637>

Roberts M.C. 2005. Update on acquired tetracycline resistance genes. FEMS Microbiol. Lett. 245(2):195-203. <https://dx.doi.org/10.1016/j. femsle.2005.02.034><PMid:15837373>

Simpson V.R. 1996. Post-mortem examination, p.69-86. In: Ibid. (Ed.), Manual of Psittacine Birds. BSAVA, Cheltenham.

Teixeira R.H.F. 2019. Ocorrência de circovírus, enterobactérias e endoparasitos em psitacídeos exóticos. Doctoral Dissertation, Universidade Estadual Paulista "Júlio de Mesquita Filho", São Paulo, p.58-63.

Yuan W., Zhang Y., Riaz L., Yang Q., Du B. \& Wang R. 2021. Multiple antibiotic resistance and DNA methylation in Enterobacteriaceae isolates from different environments. J. Hazard. Mater. 402:123822. <https://dx.doi. org/10.1016/j.jhazmat.2020.123822><PMid:33254807> 